\title{
Review
}

\section{Human colonocyte detoxification}

Detoxification or biotransformation of drugs and xenobiotics are usually linked with liver metabolism, yet colonocytes of the gastrointestinal tract have an equal capacity to mediate these processes. ${ }^{12}$ This brief overview specifically discusses the ability of human colonocytes, but not other tissues, to detoxify chemical agents and relates pertinent findings to ulcerative colitis and some aspects of colon cancer. Failure to detoxify, leading to epithelial cell damage, or an exaggerated capacity to biotransform, leading to carcinogen formation in colonocytes, have been the main implications in disease processes.

In general, two categories of detoxification processes are recognised (table 1$)^{3}{ }^{4}$ : phase I reactions concern oxidation, reduction and hydrolysis within the cytosol, and phase 2 reactions require ATP and concern conjugation with a donor substrate synthesised in the cell. Both reactions need enzymes such as oxidoreductases, hydrolases, transferases, and lyases. Amongst these may be subclasses, genetic polymorphism and variability of enzyme activity in organs and along the gastrointestinal tract. Particularly, differences in enzyme activity in the proximal and distal colon may occur. $^{56}$

Biochemists, pharmacologists, toxicologists, molecular biologists, geneticists, oncologists, and gastroenterologists are involved in this field of study, from each of which information is now drawn together. Many new toxicological advances made with liver and lung tissues still have to be applied to colonocytes and would be a fruitful area of future research. The subject of clinical gastrointestinal toxicology ${ }^{7}$ makes it possible to bridge a gap between colonic disease, genetics and the ability to detect initiating or promoting factors in ulcerative colitis and colon cancer.

\section{Cytoplasmic oxidases and reductases}

Cytochrome P-450 are a superfamily of haem containing mono-oxygenases ${ }^{8}$ acting in the metabolism of foreign compounds, as well as synthesis of steroids and bile components. The P-450 superfamily of enzymes is composed of families and subfamilies of enzymes based on amino acid differences. P-450 are designated by CYP followed by a number designating the family (1-27) and a

TABLE 1 Detoxification and biotransformation reactions found in human colonocytes

\begin{tabular}{|c|c|c|}
\hline Action & Enzyme & Substrate/cofactor \\
\hline \multicolumn{3}{|l|}{ Phase I } \\
\hline Oxidation & Cytochrome P-450 & $\mathrm{O}_{2}$ \\
\hline \multicolumn{3}{|l|}{ Hydroxylation } \\
\hline \multicolumn{3}{|l|}{ Sulphoxidation } \\
\hline \multicolumn{3}{|l|}{ Dealkylation } \\
\hline \multirow{2}{*}{\multicolumn{3}{|c|}{ Cytochrome $\mathrm{P}-450$ reductase }} \\
\hline & & \\
\hline Co-oxidation & $\begin{array}{l}\text { Peroxidases } \\
\text { Catalases }\end{array}$ & $\mathrm{H}_{2} \mathrm{O}_{2}$ \\
\hline \multirow[t]{2}{*}{ Hydrolysis } & Esterases & $\mathrm{H}_{2} \mathrm{O}$ \\
\hline & Epoxide hydrolases & \\
\hline Hydration & Carbonic anhydrase & $\mathrm{CO}_{2}+\mathrm{H}_{2} \mathrm{O}$ \\
\hline \multicolumn{3}{|l|}{ Phase II } \\
\hline Sulphation & Sulphotransferases & PAPS + ATP \\
\hline Glucuronidation & Glucuronyl transferase & UDP-GA + ATP \\
\hline Acetylation & Acetyl transferase & Acetyl-CoA + ATP \\
\hline Methylation & Methyl transferase & $\mathrm{SAM}+\mathrm{ATP}$ \\
\hline \multicolumn{3}{|l|}{ Glutathione } \\
\hline
\end{tabular}

letter for the subfamily (A-C). Subfamilies may occur in one or two forms. ${ }^{9}{ }^{10}$

The activity and expression of cytochrome P-450 in human colonocytes is generally low. ${ }^{10-12}$ The low levels of cytochrome P-450 found in human colonocytes have been attributed to methodological difficulties, but observations in the rat suggest that colonic $\mathrm{P}-450$ activity is equivalent to that in the liver. ${ }^{13}$

The activity of CYP1A2 is directed by substrates such as caffeine ${ }^{14}$ and ethanol, but certain cytochrome P-450 concentrations are greater in human adenocarcinomas, ${ }^{15}$ leading to the proposal that "activated" mono-oxygenases can convert pro-carcinogens to carcinogens ${ }^{16}$; however, other studies $^{17}$ found low levels of CYP1A1, CYP2B1 in colon cancer. Correlation of mutations of CYP1A1, normally active against polycyclic aromatic hydrocarbons acting on colonocytes, have been found in colorectal cancers of Japanese and Hawaiians but not Caucasians. ${ }^{18}$ These mutations make colonocytes vulnerable to the carcinogenic activity of polycyclic aromatic hydrocarbons. In general, polymorphic phenotypes of the oxidation of various drugs by cytochrome P-450 have been established, ${ }^{8}$ but no relation was found in patients with colon cancer.

\section{Oxidant damage control}

Reactive oxygen metabolites have been implicated in the development of radiation colitis and ulcerative colitis, yet defences against such radicals are strongly present in colonocytes. ${ }^{19}{ }^{20}$ The oxidant defence enzymes superoxide dismutase, catalase and glutathione peroxidase, are mainly present in colonocytes rather than in submucosal structures. ${ }^{6}{ }^{19}$ Distribution along the length of the gastrointestinal tract is variable, but colonic levels are lower than those found in the stomach. ${ }^{20}$ Colonocytes seem to have adequate control against oxidants such as tertiary butyl hydroperoxide with lesser effect against oxidants such as menadione. ${ }^{21}$ In ulcerative colitis antioxidant enzymes such as catalase and glutathione peroxidase are not significantly impaired $^{22}$ despite the imputation of oxygen free radicals as damaging agents.

\section{Glutathione: redox control and transfer reactions}

The effect of cellular and circulating glutathione against oxidants is considerable and plays an important role in redox control. The concentrations of glutathione in human colonocyte $^{23}{ }^{24}$ are roughly half those found in the liver. Both transport into colonocytes and synthesis of glutathione ${ }^{2526}$ occurs in colonocytes where levels can be diminished by paracetamol ${ }^{24}$ or specific inhibitors such as a buthionine sulphoxime. ${ }^{25}$ Inter-individual variation in glutathione concentrations in the colonic mucosa can be 16-fold, ${ }^{27}$ with similar variability found for glutathione peroxidase, which is involved in redox control. ${ }^{28}$ Genetic factors probably account for such variability.

In animals, bodily depletion of glutathione leads to colitis $^{25}$ and low mucosal concentrations of glutathione have been found in quiescent and active ulcerative colitis, ${ }^{29}$ suggesting that redox control by glutathione is impaired in colonocytes in this disease.

Through the action of glutathione transferases $(\alpha, \mu$ and $\pi)$, glutathione undergoes transfer to electrophilic substrates 
such as benzyl chloride or diethyl maleate, resulting in soluble complexes that are more hydrophilic and less cytotoxic. As a result of the hypothesis that chemical selection processes can cause overexpression of detoxification enzymes, glutathione transferase activity has been measured in the human colon, ${ }^{22}{ }^{30}$ in both health and disease. High activities of glutathione transferases (GST $\pi$ ) have been found in colon cancer, ${ }^{31}{ }^{32}$ which is in support of the hypothesis. A correlation in levels of GST $(\alpha, \mu$, and $\pi)$ between colonic mucosa and circulating lymphocytes has been found, ${ }^{33}$ enabling the detection of cancer prone subjects. Lowered glutathione transferase activity has been observed in ulcerative colitis, ${ }^{22}{ }^{34}$ particularly in early onset disease and more severe forms of colitis. The importance of these observations has yet to be evaluated, but proposals are that failure of detoxification may be seen as a potential factor in the development of colitis.

\section{Acetylation}

$\mathrm{N}$-acetylation in colonocytes is implicated in the biotransformation of chemical agents such as arylamine to carcinogens $s^{35}$ or inactivation (detoxification) of therapeutic agents, such as isoniazid, hydralazine, 4-aminosalicylic acid (ASA) ${ }^{37}$ and 5-aminosalicylic acid. ${ }^{38}$ Acetylation of drugs masks functional chemical groups and renders the drugs less water soluble. Acetylation is recognised in two genetic phenotypes in terms of slow and fast acetylators. ${ }^{39}$ In humans there are two $\mathrm{N}$-acetyl transferase genes (NAT1, NAT2) located on chromosome 8. NAT1 has a monomorphic pattern and NAT2 polymorphic activity, which is mainly found in liver. ${ }^{40}$

The $\mathrm{N}$-acetyl transferase activity in human colonocytes ${ }^{41}$ is as high as in the liver. Previous studies associating NAT genes in colonocytes with colorectal cancer had only shown a slightly increased odds ratio of 1.29 in association with colonic adenomas ${ }^{42}{ }^{43}$ though a combination of CYPIA2 and NAT2 have a higher odds ratio related to potential mutagen transformation in colonic epithelial cells. ${ }^{44}$ The presence of a fast acetylator phenotype in colonocytes in conjunction with high meat intake seems to predispose to colonic carcinogenesis. ${ }^{36} 39$

In ulcerative colitis acetylation of 5-ASA is prominent, ${ }^{45} 46$ yet acetylation of 5-ASA does not produce a therapeutic gain. ${ }^{38}$ Acetylation renders 5-ASA less water soluble and diminishes uptake by colonocytes. ${ }^{47}$ Acetylation of 5-ASA by colonocytes is biochemically preserved as the reaction proceeds even when mitochondrial oxidation has been reduced by more than $75 \%{ }^{48}$ The bacterial amine content of the colonic lumen is high and presumably acetylation of amines protects against their entry into the circulation and thereby potential adverse reactions on organ metabolism.

\section{Sulphation and sulphotransferases}

Sulphotransferases in epithelial cells require ATP and "activated sulphate" for sulphation of bile salts, mucopolysaccharides, catecholamines, phenols, steroids, and xenobiotics, in the process of which they alter the activity or function of each agent. Sulphotransferases for steroids ${ }^{49}$ and bile salts ${ }^{50} 51$ are not found in mammalian colonocytes; however, phenols, such as napthol or paracetamol, ${ }^{52}{ }^{53}$ catecholamines, ${ }^{54}$ and mucin ${ }^{55}$ are extensively sulphated in human colonocytes. Sulphation in colonocytes is six to eight times greater than glucuronidation of phenols in human colonocytes ${ }^{52} 53$ and there is "compartmentalisation" of sulphation depending upon luminal or contraluminal application of xenobiotics. ${ }^{56}$

In ulcerative colitis sulphation of phenols, whether measured by dialysis in vivo ${ }^{57}$ or in vitro with isolated cells, ${ }^{58}$ is significantly diminished. Such impairment could result from diminished formation of activated sulphate, diminished sulphotransferase activity or diminished supply of ATP. The latter seems to be the most likely explanation that would lead to diminished formation of activated sulphate, which also depends upon the availability of ATP. Diminished phenol detoxification may lead to continuing damage to colonocytes and perpetuation of the disease process.

Sulphation of mucin is diminished in ulcerative colitis $^{5960}$ and colon cancer. ${ }^{61}{ }^{62}$ Both biochemical and cytochemical evidence ${ }^{63}$ reveal significantly reduced ability of colonocytes to sulphate mucin in colitis. The activity of sulphotransferases has been measured in the human colon $^{6}{ }^{61}$ in the cancerous state, but not in ulcerative colitis. Sulphation of mucin ${ }^{61}$ and phenols ${ }^{52}$ are also diminished in cancer tissue. The mechanisms of diminished sulphation, respectively, in ulcerative colitis and colon cancer have not been compared further. Colonic sulphotransferases have the ability to bioactivate potential harmful agents leading to carcinogen formation. ${ }^{64}$ Both genetic and biochemical factors of either over-regulation or under-regulation of enzymes in colonocytes seem to be part of the disease process in colon cancer and ulcerative colitis, but biochemical details are lacking.

\section{Methylation and methyltransferases}

Methyltransferases subserve detoxification of xenobiotics and a number of cellular synthetic functions. Methylation depends upon O-N- and S-methyltransferases, ${ }^{65}$ all of which require the high energy cofactor S-adenosylmethionine. The function of DNA methylation ${ }^{66}$ and methylation of phospholipids in membranes ${ }^{67}$ play a part in tumorigenesis and colonic absorption ${ }^{68}$ in roles other than detoxification: these physiological functions are not discussed further.

The S-methyltransferases in colonocytes, which subserve detoxification processes, are of two functional types: those that methylate aromatic or heterocyclic sulphydryls, such as mercaptopurine (thiopurine methyltransferase, TPMT),${ }^{69}$ and those that methylate aliphatic sulphydryls, such as mercaptopropionic acid or potassium sulphide (thiol-methyltransferase, TMT).$^{70}$ Of all tissues in animals, TMT activity is highest in the colon, exceeding values in the liver with an aboral change between stomach and colon. ${ }^{71}$ In humans, however, TMT activity, although high in the large intestine, does not exceed values in the liver. ${ }^{73}$ A large number of sulphur containing xenobiotics are acted upon by TMTs. ${ }^{75}$

The activity of TMT in red blood cells is diminished in Parkinson's disease ${ }^{76}$ and rheumatoid arthritis, ${ }^{77}$ in contrast with erythrocyte values of TMT activity in ulcerative colitis which are very high compared with control cases. ${ }^{78}$ Colonocyte values of TMT activity in ulcerative colitis are unknown, but healthy colonocytes show a 10 -fold variation in activity. ${ }^{79}$ As sulphides are toxic to colonocytes, ${ }^{80}$ the activity of TMT in ulcerative colitis is an important factor in maintaining epithelial integrity. Distinction between erythrocyte, colonocyte and inflammatory cell activity of TMT in the colonic mucosa is important and needs to be considered in the disease process of ulcerative colitis. The concentration of the high energy cofactor S-adenosyl methionine, needed for TMT activity in colonocytes, is reduced in ulcerative colitis, ${ }^{81}$ suggesting a failure of capacity to detoxify sulphide by methylation. DNA hypomethylation has also been observed in ulcerative colitis. ${ }^{82}$

Variability of colonic TMT activity suggests a strong genetic control mechanism for this enzyme- genetic polymorphism for TMT activity in red blood cells has already been established. ${ }^{83-85}$ Apart from genetic factors, competition 
between $\mathrm{N}$-methylation and S-methylation in colonocytes needs to be evaluated, particularly in colon cancer and ulcerative colitis.

\section{Hydrogen ion and $\mathrm{pH}$ control}

Partially to protect against organic acid production by bacteria, bicarbonate secretion by colonocytes is high ${ }^{86} 87$ and regulated by mucosal $\mathrm{CO}_{2}$ concentrations that depend on cell metabolism or general respiratory control. Hydration of $\mathrm{CO}_{2}$ is determined by carbonic anhydrase found in apical epithelial cells of the entire colon, ${ }^{88}{ }^{89}$ but with greater activity in the proximal colon. ${ }^{90}$ Bicarbonate secretion is closely linked with absorption of sodium and chloride. ${ }^{91} 92$

In ulcerative colitis luminal acidification is associated with diminished bicarbonate secretion, ${ }^{92}{ }^{93}$ either due to diminished metabolic supply of $\mathrm{CO}_{2}{ }^{94}$ or diminished carbonic anhydrase activity. ${ }^{95}$ None of the established metabolic inhibitors of carbonic anhydrase ${ }^{96}$ are known to induce colitis, but most animal models of experimental colitis produced by acetic acid, ${ }^{97}$ propionic acid, ${ }^{98}$ TNBS, ${ }^{99}$ or hydrochloric acid ${ }^{100}$ require extreme acidic conditions to damage colonocytes. Certain volatile sulphur compounds which may occur in the colon, may act on carbonic anhydrase ${ }^{101}$ to raise the intracellular concentration of hydrogen sulphide. The role of $\mathrm{pH}$ control and the place of carbonic anhydrase for detoxification in the colon deserves further investigation, particularly with regard to ulcerative colitis.

\section{Conclusions}

Many avenues of investigation indicate that colonic epithelial cells have diverse mechanisms to detoxify luminal agents of dietary, bacterial or fermentative origin. Colonocytes are equal to hepatocytes in their capacity to carry out detoxification processes or transformation of chemical agents. The failure of detoxification in ulcerative colitis and exaggerated biotransformation in colon cancer suggest disease mechanisms worthy of further exploration.

Even though the pharmacological substances mentioned earlier are foreign to the colon, experimentation has revealed a substantial genetic diversity in the capacity of colonocytes to detoxify these agents. Pharmacogenetic findings with regard to colonic mucosal metabolism may, in the future, unravel disease pathways, particularly in colonic carcinogenesis and ulcerative colitis.

\section{WILLIAM E W ROEDIGER} WENDY BABIDGE

Colorectal Unit and Cell Physiology Laboratory, Department of Surgery of the University of Adelaide at The Queen Elizabeth Hospital, Adelaide, SA 5011, Australia

Correspondence to: Associate Professor Roediger.

Supported by a grant from the National Health and Medical Research Council of Australia to WEWR. and WB. The authors thank Mrs S Ireland for her skilful help in word processing.

1 Foster ASJ, Richter E, Lauterbach F, Hartmann F, eds. Intestinal metabolism of xenobiotics. Stuttgart: Gustav-Fischer Verlag, 1989

2 Ilett KF, Tee LBG, Reeves PT, Minchin RF. Metabolism of drugs and other xenobiotics in the gut lumen and wall. Pharmac Ther 1990;46:67-93.

3 Amdur MO, Doull J, Klaassen CD, eds. Toxicology: The basic science of poisons. 4th edn. New York: Pergamon Press, 1991

4 Testa B. The metabolism of drugs and other xenobiotics. Biochemistry of redox reactions. London: Academic Press, 1995.

5 Oshinsky RJ, Strobel HW. Drug metabolism in rat colon: resolution of enzymatic constituents and characterization of activity. Mol Cell Biochem 1987; 75:31-60.

6 Pacifici GM, Franchi M, Gervasi PG, Longo V, Simplicio P, Temellini A, et al. Profile of drug-metabolizing enzymes in human ileum and colon. Pharmacology 1989;38:137-45.

7 Dipalma JA, Cunningham JT, Herrera JI, McCaffery TD, Wolf DC. OccuDipalma JA, Cunningham JT, Herrera JI, McCaffery TD, Wolf DC. Occu-
pational and industrial toxin exposures and the gastrointestinal tract. $A m f$ pational and industrial toxin expo

8 Gonzalez FJ. Human cytochromes P-450: problems and prospects. TIPS 1992;13:346-52.

9 Ioannides I. Cytochromes P-450. Metabolic and toxicological aspects. Boca Raton: CRC Press, 1996
10 Peters WHM, Kremers PG. Cytochromes P-450 in the intestinal mucosa of man. Biochem Pharmacol 1989;38:1535-8.

11 Peters WHM, Kock L, Nagengast FH, Kremers PG. Biotransformation in human intestine: critical low levels in the colon. Gut 1991;32:408-12.

12 McKay JA, Murray GI, Weaver RJ, Ewen SWB, Melvin WT, Burke MD. Xenobiotic metabolising enzyme expression in colonic neoplasia. Gut 1993;34:1234-9.

13 Oshinsky RJ, Strobel HW. Drug metabolism in rat colon: resolution of enzymic constituents and characterization of activity. Mol Cell Biochem 1987;75:51-60.

14 Spigelman AD, Farmer KCR, Oliver S, Nugent KP, Bennett PN, Notarianni Lj, et al. Caffeine phenotyping of cytochrome P-4501A2, $\mathrm{N}$-acetyltransferase, and xanthine oxidase in patients with familial
adenomatous polyposis. Gut 1995;36:251-4.

Thies E Siegers C-P. Metal

Thies E, Siegers C-P. Metabolic activation and tumourigenesis. Prog Pharm Clin Pharm 1989;7:199-214.

Mayhew JW, Lombardi PE, Fawaz K, Goldin B, Foster EA, Goldberg M, et al. Increased oxidation of a chemical carcinogen, benzo(a)pyrene, by colon tissue specimens from patients with ulcerative colitis. Gastroenterology

17 Massaad L, De Waziers I, Ribrag U, Janot F, Beaune PH, Morizet J, et al. Comparison of mouse and human colon tumours with regard to phase I and phase II drug-metabolizing enzyme systems. Cancer Res 1992;52: 6567-75.

18 Sivaraman L, Leatham MP, Yee J, Wilkens LR, Lau AF, Marchand LL. CYP1A1 Genetic polymorphisms and in situ colorectal cancer. Cancer Res 1994;54:3692-5.

19 Grisham MB, MacDermott RA, Deitch EA. Oxidant defense mechanisms in the human colon. Inflammation 1990;14:669-80.

20 Mandhar M, Balasubramanian KA. Antioxidant enzymes in rat gastrointestinal tract. Indian f Biochem Biophys 1986;23:276-8.

21 Baskar L, Balasubramanian KA. Effect of oxidant exposure on isolated rat colonocytes. Scand f Gastroenterol 1995;30:332-6.

22 Bhaskar L, Ramakrishna BS, Balasubramanian KA. Colonic mucosal antioxidant enzymes and lipid peroxidase levels in normal subjects and patients with ulcerative colitis. $\mathcal{F}$ Gastroenterol Hepatol 1995;10:140-3.

23 Siegers C-P, Böse-Younes H, Thies E, Hoppenkamps R, Younes M. Glutathione and GSH-dependent enzymes in the tumorous and nontumorous mucosa of the human colon and rectum. F Cancer Res Clin Oncol 1984;107:238-41.

24 Jones DP. Glutathione distribution in natural products: absorption and tissue distribution. Methods Enzymol 1995;252:1-13.

25 Martensson J, Jain A, Meister A. Glutathione is required for intestinal function. Proc Natl Acad Sci USA 1990;87:1715-9.

26 Potter DW, Tran T-B. Apparent rates of glutathione turnover in rat tissues. Toxicol Appl Pharmacol 1993;120:186-93.

27 Batist G, Ishak KM, Hudson N, Demuys JM. Interindividual variation in phase II detoxification enzymes in normal human colon mucosa. Biochem Pharmacol 1988;37:4241-3.

28 Lash LH, Hagen TM, Jones DP. Exogenous glutathione protects intestinal epithelial cells from oxidative injury. Proc Natl Acad Sci USA 1986;83: $4641-5$

29 Fields J, Keshavarzian A, Eiznhamer D, Frommel T, Winship D, Holmes E. Low levels of blood and colonic glutathione in ulcerative colitis [abstract]. Gastroenterology 1994;106:A680.

30 Peters WHM, Roelofs HMJ, Nagengast FM, Van Tongeren JHM. Human intestinal glutathione S-transferases. Biochem $\mathcal{F}$ 1989;257:471-6.

31 Clapper ML, Hoffman SJ, Tew KD. Glutathione S-transferases in normal and malignant human colon tissue. Biochim Biophys Acta 1991;1096:20916.

32 Ranganathan S, Tew KD. Immunohistochemical localization of glutathione S-transferases $\alpha, \mu$ and $\mathrm{Ti}$ in normal tissue and carcinomas from human colon. Carcinogenesis 1991;12:2383-7.

33 Szarka CE, Pfeiffer GR, Hum ST, Everley LC, Balshem AM, Moore DF, et al. Glutathione S-transferase activity and glutathione S-transferase $\mu$ expression in subjects with risk for colorectal cancer. Cancer Res 1995;55:2789-93.

34 Hertervig E, Nilsson Å, Seidegard J. The expression of glutathione transferase $\mu$ in patients with inflammatory bowel disease. Scand 7 Gastrotransferase $\mu$ in patients
enterol 1994;29:729-35.

35 Lang NP, Chu DZJ, Hunter CF, Kendall DC, Flammang TJ, Kadlubar FF. Role of aromatic amine acetyl-transferase in human colorectal cancer. Arch Surg 1986:121:1259-61.

36 Roberts-Thomson IC, Ryan P, Khoo KK, Hart WJ, McMichael AJ, Butler RN. Diet, acetylator phenotype and risk of colorectal neoplasia. Lancet 1996;347:1372-4

37 Sim E, Hickman D. Polymorphism in human N-acetyltransferase-the case of the missing allele. TIPS 1991;12:211-3.

38 Travis SPL, Jewell DP. Salicylates for ulcerative colitis-their mode of action. Pharm Ther 1994;63:135-61.

39 Hein DW. Acetylator genotype and arylamine-induced carcinogenesis. Biochim Biophys Acta 1988:948:37-66.

40 Minchin RF, Kadlubar FF, Ilett KF. Role of acetylation in colorectal cancer. Mutat Res 1993;290:35-42.

41 Pacifici GM, Bencini C, Rane A. Acetyltransferase in humans: development and tissue distribution. Pharmacology 1986;32:283-91.

42 Probst-Hensch N, Haile RW, Ingles SA, Longnecker MP, Han CY, Lin BK, et al. Acetylation polymorphism and prevalence of colorectal adenomas. Cancer Res 1995;55:2017-20.

43 Rodriguez JW, Kirlin WG, Ferguson RJ, Doll MA, Gray K, Rustan TD, et al. Human acetylator genotype: relationship to colorectal cancer incidence and arylamine N-acetyltransferase expression in colon cytosol. Arch Toxicol 1993;67:445-52.

44 Kaderlik KR, Kadlubar FF. Metabolic polymorphisms and carcinogenDNA adduct formation in human populations. Pharmacogenetics 1995;5: S108-17.

45 Allgayer H, Ahnfelt NO, Kruis W, Klotz U, Frank-Holmberg K, Soderberg $\mathrm{HNA}$, et al. Colonic N-acetylation of 5-aminosalicylic acid in inflammatory bowel disease. Gastroenterology 1989;97:38-41.

46 Ireland A, Priddle JD, Jewell DP. Acetylation of 5-aminosalicylic acid by isolated human colonic epithelial cells. Clin Sci 1990;78:105-11.

47 Ireland A, Priddle JD, Jewell DP. Comparison of 5-aminosalicylic acid and $\mathrm{N}$-acetylaminosalicylic acid uptake by the isolated human colonic epithelial cell. Gut 1992;33:1343-7. 
48 Babidge W, Millard S, Roediger W. Effect of sodium hydrogen sulfide and butyrate on acetylation of 5-aminosalicylic acid in isolated rat colonocytes. Med Sci Res 1994;22:219-20.

49 Boström H, Brömster D, Nordenstam H, Wengle B. On the occurrence of phenol and steroid sulphokinases in the human gastrointestinal tract. Scand $\mathcal{f}$ Gastroenterol 1968;3:369-75.

50 Lööf L, Wengle B. Enzymatic sulphation of bile salts in man. Scand f Gastroenterol 1979;14:513-19.

51 Dew MJ, Hawker PC, Nutter S, Allan RN. Human intestinal sulphation of lithocolate: a new site for bile acid metabolism. Life Sci 1980;27:317-23.

52 Cohen GM, Grafstrom RC, Gibby EM, Smith L, Autrup H, Harris CC. Metabolism of benzo(a)pyrene and 1-naphthol in cultured human tumorous and non tumorous colon. Cancer Res 1983;43:1312-5.

53 Ramakrishna BS, Gee D, Weiss A, Pannall P, Roberts-Thomson IC, Roediger WEW. Estimation of phenolic conjugation by colonic mucosa. 7 Clin hol 1989;42:620-3.

54 Pacifici GM, Eligi M, Giuliani L. (+) and (-) terbutoline are sulphated at a higher rate in human intestine than liver. Eur $f$ Clin Pharmacol 1993; 45:483-7.

55 Filipe MI. Value of histochemical reactions for mucosubstances in the diagnosis of certain pathological conditions of the colon and rectum. Gut 1969; 10:577-86.

56 Lauterbach F, Czekay R-P, Sund RB. Compartmentation of intestinal drug sulphoconjugation. Biochem Pharmacol 1993;46:1339-47.

57 Ramakrishna BS, Roberts-Thomson IC, Pannall PR, Roediger WEW. Impaired sulphation of phenol by the colonic mucosa in quiescent and active ulcerative colitis. Gut 1991;32:46-9.

58 Roediger WEW. The role of sulphur metabolism and mercapto fatty acids in the aetiology of ulcerative colitis. In: Goebell $\mathrm{H}$, Malchow $\mathrm{H}$, Ewe K, Koelbel Ch, eds. Inflammatory bowel disease. Progress in basic research and clinical implications. Lancaster, UK: Kluwer Academic Publishers, 1991:17-27.

59 Raouf AH, Tsai HH, Parker N, Hoffman J, Walker RJ, Rhodes JM. Sulphation of colonic and rectal mucin in inflammatory bowel disease: reduced tion of colonic and rectal mucin in inflammatory bowel disease: reduced

60 Corfield AP, Wagner SA, O'Donnell LJD, Durdey P, Mountford RA, Clamp JR. The role of enteric bacterial sialidase, siolate, O-acetyl esterase and glycosulfatase in the degradation of human colonic mucin. Glycoconj $\mathcal{F} 1993$; 10:72-81.

61 Yamori T, Kimura H, Stewart K, Ota DM, Cleary KR, Irimura T. Differential production of high molecular weight sulfated glyco-proteins in normal colonic mucosa, primary colon carcinoma and metastases. Cancer Res 1987;47:2741-7.

62 Corfield AP, Myerscough N, Gough M, Brockhausent I, Schauer R, Paraskeva C. Glycosylation patterns of mucin in colonic disease. Biochem Soc Trans 1995;23:840-5.

63 Jass JR, Robertson AM. Colorectal mucin histochemistry in health and disease: a critical review. Pathol Int 1994;44:487-504.

64 Chou H-C, Lang NP, Kadlubar FF. Metabolic activation of the $\mathrm{N}$-hydroxyderivative of the carcinogen 4 -aminobiphenyl by human tissue sulfotransferases. Carcinogenesis 1995;16:413-17.

65 Creveling CR, Thakker DR. O-, N- and S-methyltransferases. In: Kauffman FC, ed. Conjugation-deconjugation reactions in drug metabolism and toxicity. Berlin: Springer-Verlag, 1993:189-216.

66 Counts JL, Goodman JI. Alterations in DNA methylation may play a variety of roles in carcinogenesis. Cell 1995:83:13-15.

67 Dudeja PK, Foster ES, Brasitus TA. Synthesis of phosphatidylcholine by two distinct methyltransferases in rat colonic brush-border membranes: evidence for extrinsic and intrinsic membrane activities. Biochim Biophys evidence for extrinsic a
Acta $196 ; 875: 493-500$

68 Brown MD, Dudeja PK, Brasitus TA. S-adenosyl-L-methionine modulates $\mathrm{Na}^{+}+\mathrm{K}^{+}$-ATPase activity in rat colonic basolateral membranes. Biochem $\mathcal{f}$ 1988;251:215-22.

69 Weinshilboum R. Thiol S-methyltransferases, I: Biochemistry. In: Damani LA, ed. Sulphur-containing drugs and related compounds. Vol 2A. Chichester: Ellis Horwood, 1989:121-42.

70 Bremer J, Greenberg DM. Enzymic methylation of foreign sulfhydryl compounds. Biochim Biophys Acta 1961;46:217-24.

71 Weisiger RA, Pinkus LM, Jakoby WB. Thiol S-methyltransferase: suggested role in detoxication of intestinal hydrogen sulfide. Biochem Pharmacol 1980;29:2885-7.

72 Weisiger RA, Jakoby WB. S-methylation: thiol S-methyltransferase. In: Jakoby WB, ed. Enzymatic basis of detoxication. Vol II. New York: Academic Press, 1980:131-40.

73 Pacifici GM, Santerini S, Giuliani L, Rane A. Thiol methyltransferase in humans: development and tissue distribution. Dev Pharmacol Ther 1991;17:8-15.

74 Pacifici GM, Romiti P, Santerini S. Giuliani L. S-methyltransferases in human intestine: differential distribution of the microsomal thiol methyltransferase and cytosolic thiopurine human bowel. Xenobiotica 1993;23:671-9.
75 Crooks PA. Interactions of sulphur-containing xenobiotics with S-adenosylL-methionine-dependent methyl transferases. In: Damani LA, ed. Sulphurcontaining drugs and related organic compounds. Chichester: Ellis Horwood, 1989:47-85

76 Waring RH, Sturman SG, Smith MCG, Steventon GB, Heafield MTE, William AC. S-methylation in motor neuron disease and Parkinson's disease. Lancet 1989;ii:356-7.

77 Bradley H, Waring RH, Emery P. Reduced thiol methyl transferase activity in red blood cell membranes from patients with rheumatoid arthritis. $\mathcal{F}$ Rheumatol 1991;18:1787-9.

78 Pitcher MCL, Beatty ER, Harris RM, Waring RH, Cummings JH. Detoxification of luminal xenobiotics in ulcerative colitis [abstract]. Gastroenterology 1996;110:A1740.

79 Babidge WJ, Millard SH, Roediger WEW. Thiol methyltransferase activity in colonocytes and erythrocyte membranes. F Clin Pathol 1995;48:641-4.

80 Roediger WEW, Duncan A, Kapaniris O, Millard S. Reducing sulfur compounds of the colon impair colonocyte nutrition: implications for ulcerative colitis. Gastroenterology 1993;104:802-9.

81 Thiede C, Bayerdörffer E, Thiede H-M, Ochsenkühn T, Neubauer A. Quantification of the essential methyl group donor S-adenosyl-methionine in human colorectal mucosa of patients with inflammatory bowel disease (IBD) and colorectal adenomas [abstract]. Gastroenterology 1995;108:
A546.

82 Cravo M, Gloria L, De Sousa S, Chaves P, Pereira AD, Quina M, et al. Folate status, DNA methylation and colon cancer risk in inflammatory .

83 Weinshilboum R. Thiol S-methyltransferases, II: Pharmacogenetics. In: Damani LA, ed. Sulphur-containing drugs and related organic compounds. Chichester: Ellis Horwood, 1989:143-57.

84 Keith RA, Van Loon J, Wussow LF, Weinshilboum RM. Thiol methylation pharmacogenetic heritability of human erythrocyte thiol methyltransferase activity. Clin Pharmacol Ther 1983;34:521-8.

85 Waring $\mathrm{RH}$ and Emery P. Genetic factors predicting persistent disease: the role of defective enzyme systems. Baillieres Clin Rheumatol 1992;6:337-50.

86 Roediger WEW, Lawson MJ, Kwok V, Kerr Grant A, Pannall PR. Colonic bicarbonate output as a test of disease activity in ulcerative colitis. $\mathcal{F}$ Clin Pathol 1984;37:704-7.

87 Charney AN, Wagner JD, Birnbaum GT, Johnstone JN. Functional role of carbonic anhydrase in intestinal electrolyte transport. Am $\mathcal{f}$ Physiol 1986;251:S682-7.

88 Spicer SS, Sens MA, Tashian RE. Immunocytochemical demonstration of carbonic anhydrase in human epithelial cells. $\mathcal{F}$ Histochem Cytochem 1982;30:864-73.

89 Gramlich TL, Hennigar RA, Spicer SS, Schulte A. Immunohistochemical localization of sodium-potassium-stimulated adenosine triphosphatase and carbonic anhydrase in human colon and colonic neoplasms. Arch Pathol Lab Med 1990;114:415-9.

90 Swenson ER. Distribution and functions of carbonic anhydrase in the gastrointestinal tract. In: Dodgson SJ, Tashian RE, Gros G, Carter ND, eds. The carbonic anhydrases. New York: Plenum Press, 1991:265-87.

91 Parsons DS. Role of anions and carbonic anhydrase in epithelia. Phil Trans $R$ Soc Lond 1982;299:369-81.

92 Roediger WEW, Heyworth M, Willoughby P, Piris J, Moore A, Truelove SC. Luminal ions and short chain fatty acids as markers of functional activity of the mucosa in ulcerative colitis. F Clin Pathol 1982;35:323-6.

93 Caprilli R, Frieri G, Latella G, Vernia P, Santoro ML. Faecal excretion of bicarbonate in ulcerative colitis. Digestion 1986;35:136-42.

94 Roediger WEW. The colonic epithelium in ulcerative colitis: an energy deficiency disease. Lancet 1980;ii:712-5.

95 Latella G, Fonn R, Caprilli R, Frieri G, Plateroti M, Sambuy Y. Carbonic anhydrase 1. Expression in colonic mucosa of patients with ulcerative colitis [abstract]. Gastroenterology 1995;108:A858.

96 Maren TH, Sanyal G. The activity of sulfonamides and anions against the carbonic anhydrases of animals, plants and bacteria. Ann Rev Pharmacol Toxicol 1983;23:439-59.

97 MacPherson BR, Pfeiffer CJ. Experimental production of diffuse colitis in rats. Digestion 1978;17:135-50.

98 Clark DA, Thompson JE, Weiner LB, McMillan JA, Schneider AJ, Rokahr JE. Necrotizing enterocolitis: intraluminal biochemistry in human neonates and a rabbit model. Pediatr Res 1985;19:919-21.

99 Seo HG, Takata I, Nakamuro M, Tatsumi H, Suzuki K, Fujii J, Taniguchi N. Induction of nitric oxide synthase and concomitant suppression of superoxide dismutases in experimental colitis in rats. Arch Biochem Biophys 1995;324:41-7.

100 Feil W, Lacy ER, Wong Y-MM, Burger D, Wenzl E, Starlinger M, Schiessel R. Rapid epithelial restitution of human and rabbit colonic mucosa. Gastroenterology 1989;97:685-701.

101 Chengelis CP, Neal RA. Studies of carbonyl sulfide toxicity: metabolism by carbonic anhydrase. Toxicol Appl Pharm 1980;55:198-202. 